\title{
Effect of hyperlipidaemia on pulmonary diffusing capacity for carbon monoxide
}

\author{
M R PARTRIDGE, J M B HUGHES, AND G R THOMPSON
}

From the Department of Medicine, Royal Postgraduate Medical School, and MRC Lipid Metabolism Unit, Hammersmith Hospital, London W12, UK

ABSTRACT There is conflicting evidence on the effect of hyperlipidaemia on pulmonary diffusing capacity for carbon monoxide (DLCO or TLCO) in man. We have measured the carbon monoxide transfer factor per unit alveolar volume (TLCo/VA or KCo) by the single breath method in 25 patients with hyperlipidaemia, and in three normal subjects before and after infusions of an intravenous fat emulsion, Intralipid. Non-smokers with hyperlipidaemia had normal levels of TLCO/VA, whereas some of the smokers showed a slight reduction. In neither group was there any correlation of TLCO/VA with serum triglyceride or cholesterol concentrations. A reduction in triglyceride concentrations of up to five-fold produced by plasma exchange (three studies in two patients) or by dietary manipulation (one patient) had no significant effect on the levels of TLCO/VA. Intralipid infusion in three normal subjects caused a four- to five-fold increase in serum triglyceride concentration but had no effect on TLCo/VA. We conclude that moderate degrees of hyperlipidaemia have no effect on pulmonary diffusion.

There is conflicting evidence on the effect of hyperlipidaemia on pulmonary diffusing capacity for carbon monoxide (DLCO or TLCO) in man. Enzi et al (1976) measured DLco by the steady state method in 17 patients with hyperlipidaemia and compared the results with normal subjects of the same age, height, and with similar smoking habits. They found Duco to be significantly lower in the hyperlipidaemic patients, with a negative correlation between plasma triglyceride and DLco values but no correlation between DLCo and plasma cholesterol. It was surprising, perhaps, that when Newball et al (1975) increased or decreased serum triglyceride concentrations (by dietary means) in both normal subjects and hyperlipidaemic patients there was no significant change of DLCO, even at extremes of triglyceride concentration. This was true both for short-term changes in serum triglyceride, such as during oral fat tolerance tests, and for hyperlipidaemic patients observed over longer periods.

The results quoted above were obtained in patients with spontaneously occurring or dietinduced hyperlipidaemia. In addition, small changes in gas exchange have been shown after inducing hyperlipidaemia in normal subjects by intravenous administration of a fat emulsion. Sundström et al (1973) showed a 15\% fall in steady state DLco during infusion of $20 \%$ Intralipid, with the DLCo returning to normal by 45 minutes after the end of the infusion. The alveolar-arterial oxygen gradient decreased. Analysis of their results shows considerable intersubject variation and, as they point out the decrease in Deco was small and without clinical significance in healthy subjects. Similar changes have been observed by Greene et al (1976), who used $10 \%$ Intralipid.

The mechanisms concerned in these changes are not understood. In awake sheep, McKeen et al (1978) showed that Intralipid infusions caused a rise in pulmonary artery pressure (and vascular resistance), an increase in lymph flow (but no oedema), and a fall in arterial $\mathbf{P o}_{2}$. These responses were blocked by prior treatment with indomethacin but not by heparin, which was given to prevent the rise in serum triglyceride concentration. The authors speculated that the arachidonic acid in the infusion might have increased the synthesis of prostacyclic endoperoxides. Diffusion was not measured.

The present study attempts to resolve the issue 
of whether hyperlipidaemia (either spontaneous or induced) significantly affects pulmonary diffusing capacity. We have, therefore, measured TLCO in hyperlipidaemic patients, some of whom were studied before and after plasma exchange, and in normal subjects before and after Intralipid infusions.

\section{Methods}

Twenty-five patients attending the lipid clinic at the Hammersmith Hospital were studied. There were 20 men and five women aged from 22-66 years (mean 45). Eight had never smoked, eight had stopped smoking for at least two years, and 14 were either still smoking or had only recently stopped. One of the patients was diabetic and one two months' pregnant; all the patients accepted for the study had normal chest radiographs and an $\mathrm{FEV}_{1} / \mathrm{VC}$ ratio of more than $70 \%$. All the patients attended in the morning after an overnight fast, and blood samples were taken for haemoglobin estimation and serum triglyceride and cholesterol concentrations. Diffusing capacity for carbon monoxide was measured by the single breath method (Ogilvie et al, 1957) in the sitting position. The mean of three measurements was taken, corrected for haemoglobin concentration, and results expressed as TLCo/VA or Kco. Predicted values were those of Cotes and Hall (1970).

Three normal male, non-smoking, fasting volunteers were given $200 \mathrm{ml}$ of $20 \%$ Intralipid* by intravenous infusion over 30 minutes. Diffusing capacity, serum lipid concentration, and $\mathrm{Hb}$ estimations were performed preinfusion, immediately postinfusion, and serially for up to two hours afterwards. The experiments were repeated on another day under identical conditions, except that each subject was given a $200 \mathrm{ml}$ infusion of intravenous egg lecithin (ie Intralipid without its triglyceride). This constitutes a more appropriate control than either dextrose or saline solutions.

In two patients who were undergoing weekly plasma exchange in an attempt to induce regression of their coronary artery disease, carbon monoxide diffusing capacity, serum triglyceride, cholesterol, and haemoglobin were measured immediately before and after plasma exchange of 3.2 to 4 litres using a plasma protein fraction (PPF) continuous fluid cell separator. Patient 1 had mild type IV hypertriglyceridaemia, whereas patient 2 had familial hypercholesterolaemia, with a type IIb phenotype.

*Intralipid contains soya bean oil $100 \mathrm{~g}$, egg lecithin $6 \mathrm{~g}$, and glycerol $12.5 \mathrm{~g}$ per $500 \mathrm{ml}$.

\section{Results}

The 25 patients had fasting scrum triglyceride 흘 concentrations ranging from 1.5 to $30.3 \mathrm{mmol} / 1 \frac{\text { के }}{\partial}$ (normal range: men $<2.0 \mathrm{mmol} / 1$; women $<1.5 \stackrel{\Phi}{\circ}$ $\mathrm{mmol} / \mathrm{l})$ and a serum cholesterol varying from $3.7-9.9 \mathrm{mmol} / 1$ (normal range $<6.5 \mathrm{mmol} / \mathrm{l}$ ). We $\vec{\circ}$

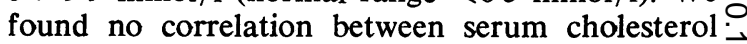
and TLCo/VA (fig 1), nor between serum trigly- $\vec{\omega}$ ceride and Kco (fig 2). In the non-smoking group all patients had a Kco within the predicted range; $\overrightarrow{\vec{x}}$ among the smokers there was a wider scatter of $\omega_{\perp}$ Kco but still no correlation with serum triglyceride concentration. Serial measurements of $\tilde{\sigma}$ diffusing capacity were made on one patient with $\mathrm{O}$ severe type $\mathrm{V}$ hyperlipidaemia whose serum trigly- $\frac{\mathrm{O}}{\mathrm{C}}$ ceride concentration was progressively lowered by $\rightarrow$ dietary fat restriction over several weeks. The $\frac{\vec{O}}{0}$ Kco remained within the predicted range at serum triglyceride concentrations, which varied from $12 \overrightarrow{0}$ to $30 \mathrm{mmol} / 1$ (ie from six to 15 times the upper 6 limit of normal).

The results of increasing serum triglyceride concentrations by a fat emulsion load are shown in table 1. Haemoglobin concentrations varied only slightly but each Kco measurement was $\stackrel{D}{D}$ corrected for the haemoglobin concentration recorded at the same time. After Intralipid, Kco averaged $96 \%$ of its initial value. The postinfusion values did not differ significantly from the pre-

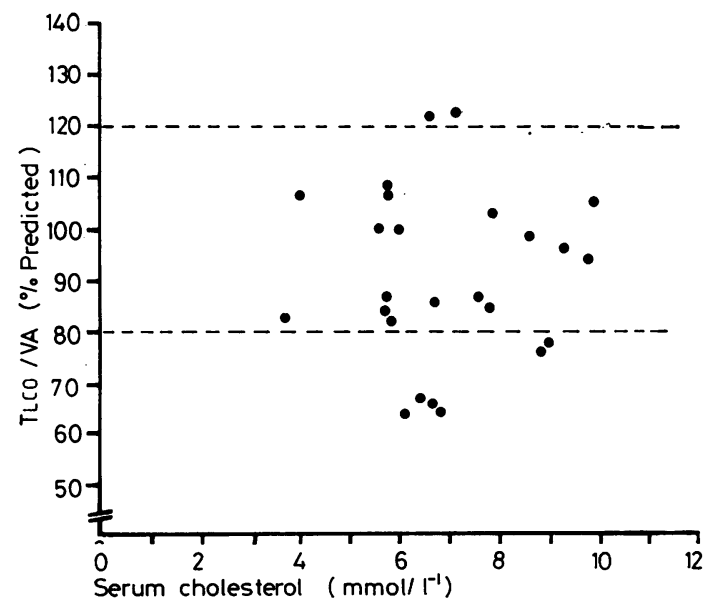

Fig 1 Carbon monoxide uptake (TLCO/VA or KCO) as percentage predicted plotted against serum cholesterol in patients with hyperlipidaemia. Interrupted lines represent predicted range for TLCo/VA (mean $\pm 1 S D)$. Upper limit of normal for serum cholesterol is $6.5 \mathrm{mmol} / \mathrm{l}$. There is no correlation. 
Table 1 Serum triglyceride concentrations and changes in Co uptake $(\mathrm{KCO})$ in three normal subjects before and after infusions of fat emulsion and egg lecithin

\begin{tabular}{|c|c|c|c|c|c|c|}
\hline & \multicolumn{2}{|l|}{ Subject $A$} & \multicolumn{2}{|l|}{ Subject B } & \multicolumn{2}{|l|}{ Subject $C$} \\
\hline & $\begin{array}{l}\text { Serum } \\
\text { triglyceride } \\
\text { concentration } \\
(\text { mmol/l) }\end{array}$ & $\begin{array}{l}\text { Kco } \\
(\text { as \% initial } \\
\text { value })\end{array}$ & $\begin{array}{l}\text { Serum } \\
\text { triglyceride } \\
\text { concentration } \\
\text { (mmol/l) }\end{array}$ & $\begin{array}{l}\text { Kco } \\
\text { (as \% initial } \\
\text { value) }\end{array}$ & $\begin{array}{l}\text { Serum } \\
\text { triglyceride } \\
\text { concentration } \\
(\text { mmol } / l)\end{array}$ & $\begin{array}{l}\text { KCo } \\
\text { (as \% initial } \\
\text { value) }\end{array}$ \\
\hline $\begin{array}{l}\text { Fat emulsion } \\
\text { Preinfusion } \\
\text { End infusion } \\
1 \mathrm{hr} \text { postinfusion } \\
2 \mathrm{hr} \text { postinfusion }\end{array}$ & $\begin{array}{l}0 \cdot 7 \\
2 \cdot 9 \\
1 \cdot 0\end{array}$ & $\begin{array}{r}100 \\
100 \\
95\end{array}$ & $\begin{array}{l}1 \cdot 0 \\
4 \cdot 9 \\
2 \cdot 5\end{array}$ & $\begin{array}{r}100 \\
89 \\
90\end{array}$ & $\begin{array}{l}1 \cdot 7 \\
8 \cdot 0 \\
7 \cdot 1 \\
4 \cdot 2\end{array}$ & $\begin{array}{r}100 \\
98 \\
96 \\
90\end{array}$ \\
\hline $\begin{array}{l}\text { Egg lecithin } \\
\text { Preinfusion } \\
\text { End infusion } \\
1 \text { h postinfusion } \\
2 \text { h postinfusion }\end{array}$ & $\begin{array}{l}1.0 \\
0.9\end{array}$ & $\begin{array}{l}100 \\
118 \\
101\end{array}$ & $\begin{array}{l}0.9 \\
1.0\end{array}$ & $\begin{array}{r}100 \\
104 \\
93\end{array}$ & $\begin{array}{l}1 \cdot 2 \\
1 \cdot 3\end{array}$ & $\begin{array}{l}100 \\
103 \\
104 \\
109\end{array}$ \\
\hline
\end{tabular}

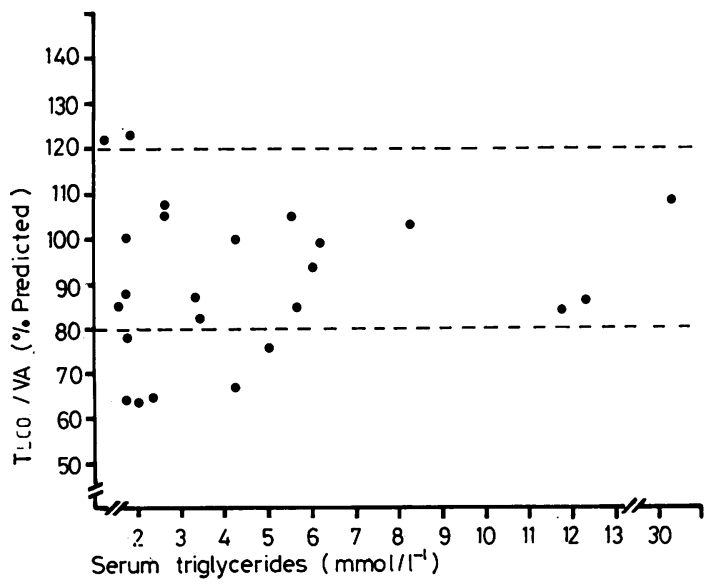

Fig 2 Carbon monoxide uptake as in fig 1 plotted against serum triglyceride concentration for same group of patients. Upper limit of normal for serum triglyceride is $1.5 \mathrm{mmol} / \mathrm{l}$ for women and 2.0 for men. Note lack of correlation.

infusion values. Furthermore, when the experiment was repeated with egg lecithin alone, there was again no significant difference between the Kco before and after infusion, nor was there a significant change of $\mathrm{KcO}$ in a paired $t$ test when the effect of one infusion was matched with the other.

Plasma exchange, which induces a significant fall in plasma triglyceride concentration, was performed on three occasions in two patients. Table 2 shows Kco before and after plasma exchange. There was no correlation between triglyceride concentration and Co uptake. One subject was followed for 93 hours after plasma exchange while the serum triglyceride concentration varied between 37 and $188 \%$ of its initial value (fig 3 ).
There was no statistical correlation between change in triglyceride concentration and change in $\mathrm{KcO}$.

Table 2 Effect of plasma exchange on serum triglyceride concentrations and carbon monoxide uptake (Kco)

\begin{tabular}{|c|c|c|c|}
\hline & \multicolumn{3}{|c|}{ Post-plasma exchange } \\
\hline & \multicolumn{2}{|c|}{ Serum triglyceride } & \multirow{2}{*}{$\begin{array}{l}\text { KCo } \\
\% \\
\text { Pre-exchange } \\
\text { value }\end{array}$} \\
\hline & $\begin{array}{l}\text { Basal level } \\
\text { (mmolll) }\end{array}$ & $\begin{array}{l}\% \\
\text { Pre-exchange } \\
\text { value }\end{array}$ & \\
\hline $\begin{array}{l}\text { Patient } 1 \\
\quad \text { (1st occasion) }\end{array}$ & $2 \cdot 7$ & 37 & 118 \\
\hline $\begin{array}{l}\text { Patient } 1 \\
\quad \text { (2nd occasion) }\end{array}$ & $1 \cdot 7$ & 21 & 91 \\
\hline Patient 2 & $2 \cdot 0$ & 45 & 102 \\
\hline
\end{tabular}

\section{Discussion}

These results do not confirm previous work which suggested an effect of spontaneous hyperlipidaemia on the pulmonary diffusing capacity for carbon monoxide. Nearly all our patients with hyperlipidaemia had normal diffusing capacities; a negative correlation with serum triglyceride concentrations was not seen. Although the triglyceride concentrations were not as high in our patients as in some of those in the Padua series (Enzi et al, 1976), a trend would have been expected even with less severe hypertriglyceridaemia. In addition, changes in triglyceride concentration with dietary restriction or plasma exchange were not correlated with changes of diffusing capacity, which is in keeping with the finding of Newball et al (1975). The reason for the rise in Kco after plasma-exchange in one patient (fig 3 ), which was 


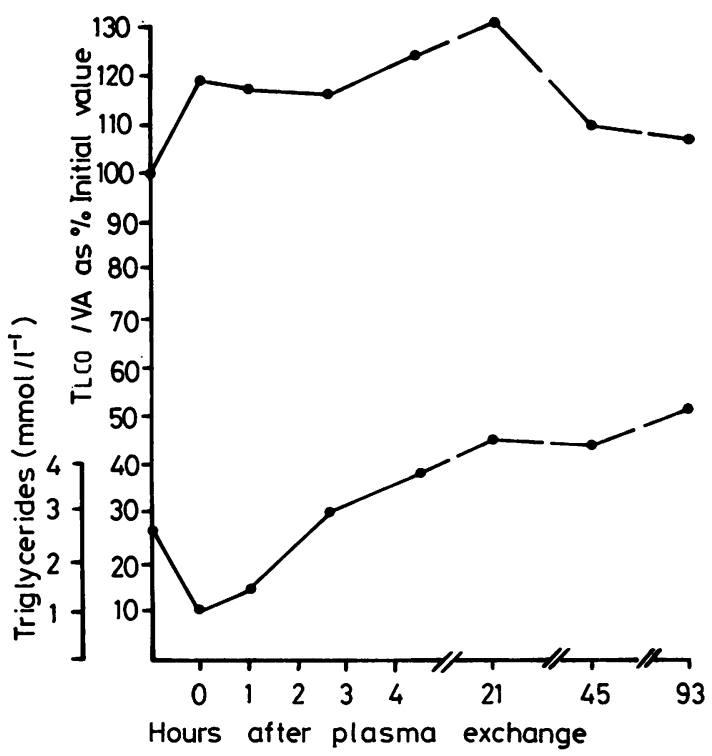

Fig 3 Patient 1. Change of Co uptake (TLCO/VA) and serum triglyceride concentration before and for 93 hours after plasma exchange.

sustained for at least 21 hours, is not clear. A significant fall in plasma viscosity is known to occur after plasma exchange, and this or some other factor may have led to an increase in pulmonary capillary blood volume.

In normal subjects our aim was to exclude the lecithin component of Intralipid as a cause of the reduction of DLCo reported previously (Sundström et al (1973); Greene et al (1976)). In fact, we were unable to find the small fall in DLco observed by them. The effect of infusing $200 \mathrm{ml}$ Intralipid in normal subjects is minimal, and we conclude that moderately raised blood lipid concentrations have no deleterious effects on pulmonary diffusion.

\section{References}

Cotes, J E, and Hall, A M (1970). The transfer factor for the lung; normal values in adults. In Normal. Values for Respiratory Function in Man, edited by $\overrightarrow{\vec{A}}$ P Arcangeli, p 327. Panminerva Medica, Torino.

Enzi, G, Bevilacqua, M, and Crepaldi, G (1976). Disturbances in pulmonary gaseous exchange in $\times$ primary hyperlipotroteinemias. Bulletin europeen $\omega_{A}$ physiopathologie respiratoire, 12, 433-442.

Greene, H L, Hazlett, D, and Demaree, R (1976) Re- N lationship between intralipid-induced hyperlipemia or and pulmonary function. American Journal of $ㅇ$ Clinical Nutrition, 29, 127-135.

McKeen, C R, Brigham, K R, Bowers, R E, and $\vec{D}$ Harris, T R (1978). Pulmonary vascular effects of fat emulsion infusion in unanaesthetized sheep. Journal of Clinical Investigation, 61, 1291-1297.

Newball, H H, Friedewald, W T, Roberts, B, Levy, ढ़ R I, and Lenfant, C J (1975). Effect of elevated triglycerides on the diffusing capacity of man. American Review of Respiratory Diseases, 112, 8388.

Ogilvie, C M, Forster, R E, Blakemore, W S, and Morton, J W (1957). A standardized breath-holding $\unrhd$ technique for the clinical measurement of the diffus- $\overrightarrow{\vec{O}}$ ing capacity of the lung for carbon monoxide. Journal of Clinical Investigation, 36, 1-17.

Sundström, G, Zauner, $\mathbf{C ~ W}$, and Arborelius, $M$ jun (1973). Decrease in pulmonary diffusing capacity during lipid infusion in healthy men. Journal of Applied Physiology, 34, 816-820.

Requests for reprints to: Dr M R Partridge, Medical Unit, Middlesex Hospital, London W1. 